Berg Huettenmaenn Monatsh (2021) Vol. 166 (11): 523-524 https://doi.org/10.1007/s00501-021-01167-2

(C) Austrian Society for Metallurgy of Metals (ASMET) and Bergmännischer Verband Österreich (BVÖ) 2021

\title{
Foreword
}

\author{
Josef Faderl, Frank Goodwin, and Gerhard Hackl
}

International Zinc Association, Durham, USA

Accepted October 8, 2021; published online October 29, 2021

The Galvatech 2021 virtual conference was held 21-23 June under the administrative leadership of ASMET. In total, 400 participants joined the conference: $62 \%$ of the 400 participants were from Europe, 19\% from Asia, 17\% from the Americas, $2 \%$ from Australia and 1\% from Africa. The program was organized into 9 broad technical areas that included 163 presentations of papers published in the Conference Proceedings available from ASMET, covering all aspects of zinc-coated steel processing, properties and applications. These included advances in advanced high strength steel metallurgy relevant to galvanizing, hot press forming of zinc-coated ultra high strength steels, corrosion performance and hydrogen effects, and current issues in forming and welding the newest zinc-coated automotive steels.

A special session on the industrial status of galvanizing production technology included lectures from the suppliers of galvanizing lines; these lines are increasingly automated and use high-level data analysis to optimize use of energy and improve productivity. One session each was devoted to the latest developments in electrogalvanizing and vapor deposition coating processes. Improvements in the efficiency of zinc use was covered in several sessions on galvanizing bath management and new developments in bath hardware and coating thickness control.

As is customary in the Galvatech conference program, a series of plenary lectures opened the conference, given by technical leaders from regions of the world producing advanced zinc-coated steels. In this issue of BHM, you will find a selection of papers from this conference that represent the latest and most interesting developments in the field of zinc-coated steel technology.

The Conference Chairs wish to thank all who participated in Galvatech 2021. This includes the presenters and session chairs who were required to adapt to the special challenges of a virtual conference, the sponsors and exhibitors who gave a real vote of confidence in their support of this virtual conference, the ASMET staff for their leadership in this new virtual world, and all participants who joined in the Q\&A and breakout sessions that allowed each person to enjoy the kind of interactions that are normally of great value during an in-person conference.

Galvatech 2023 will be held in Seoul, October 15-19. This will be followed by Galvatech 2026 in Monterrey, Mexico and Galvatech 2029 in Japan.
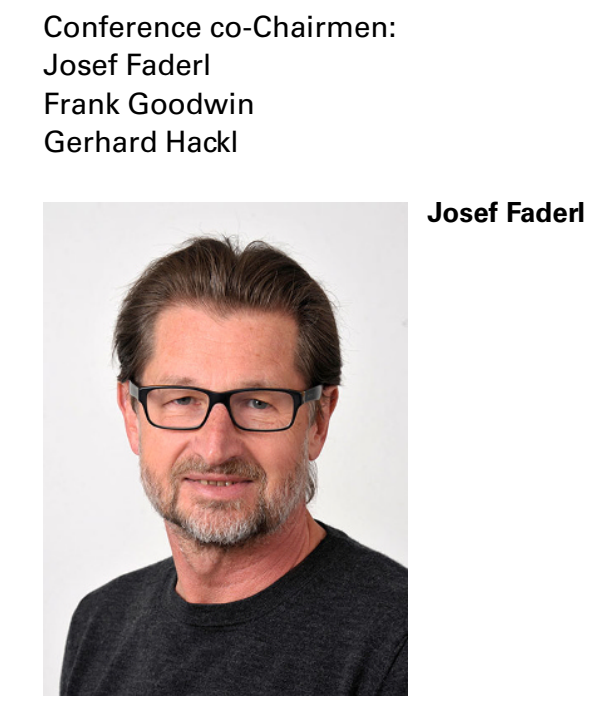

\author{
F. Goodwin (ه) \\ International Zinc Association, \\ 2530 Meridian Parkway, Suite 115 Durham, NC 27713, USA \\ fgoodwin@zinc.org
}

Josef Faderl

Hüttenmännische

Monatshefte 


\section{Frank Goodwin}

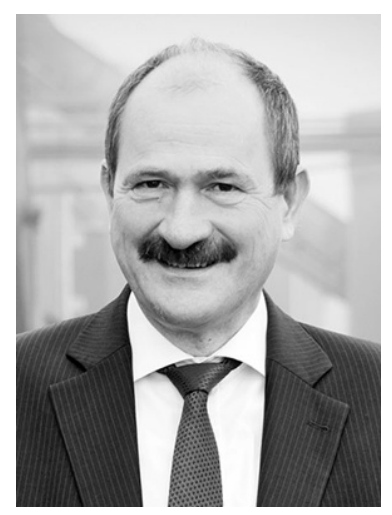

Gerhard Hackl

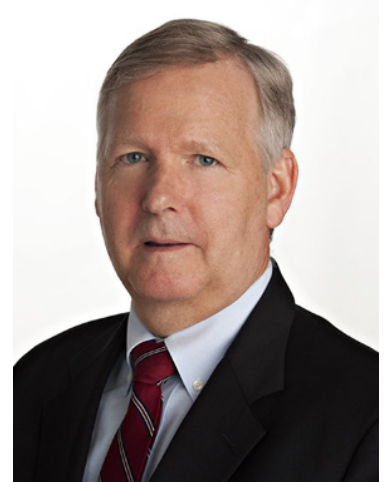

